\title{
Relational, Political, Exposed: A Reflection on Embodied Subjectivities and Public Space
}

Federica Castelli, University of Roma Tre

\begin{abstract}
This paper focuses on the link between bodies and public space, proposing a reflection on embodied subjectivities and embodied practices of performing in public space. It takes into account bodies as political means and sites of resistance, revolt, reinvention, and creation, following an embodied and feminist approach. This paper aims to underline the fact that bodies are political and that an embodied approach to public space is fundamental in order to re-think contemporary democracies. It will show how the embodied and feminist approach can provide essential tools to undo the modern idea of an absolute individual subject that lies at the heart of the neoliberal vision, pinpointing dependency, relationship, and vulnerability as defining attributes of being human. This approach has been giving life to new visions of politics, such as those we have seen embodied in a number of protests and political practices of dissent marking the latest years, here investigated in their political potential for a reshaping of the democratic public space.
\end{abstract}

Keywords: Bodies, public space, embodied subjectivities, feminisms, feminist theory

\section{Introduction}

This paper moves from a specific urgency, both theoretical and political, rooted in a number of issues arisen from our recent past, namely the revolts of 2011 and later years. These events shone a spotlight on the links among bodies, poli- 
tics, and public space, links that have been typically abused - or, on the contrary, removed - by traditional western political theories. Some contradictions linked to the latest evolution of neoliberalism have clearly shown the urgency of a serious and new reflection on this point. This paper proposes then a reflection on bodies as political means and sites of resistance, revolt, reinvention, and creation, and a focus on embodied practices of performing in public space. It will take into account bodies - as gendered bodies - not as a mere issues, a topic or a subject matter for a general argumentation. Rather, it is rooted in a feminist embodied approach (such as those of Cavarero, Irigaray, Lonzi, Giardini, and many others in this paper). The embodied approach unveils a political dimension, both practical and philosophical, that tells something about our being, as human beings, in the world. The body is not only something on and "about" which discussions and knowledge can be produced. It is a means of political creation.

The first section investigates classical representations of the relationship between body and politics in western political thinking. Then, the paper will show how the feminist approach, namely the Italian feminist theory in Seventies and Eighties, has led political thinking toward the idea of embodied subjectivities and politics as political practices, relationships, and embodied action in concert. This embodied approach to subjectivities has put into question the traditional relationship between body and politics, and opened up to a new philosophical and political vision, far from the sovereign, isolated, subject of modern philosophy (as underlined in section 4). The last part of the paper is focused on the embodied practices of dissent marking the latest years, in order to investigate their political potential for a reshaping of the democratic public space.

The specific thesis of this paper is that bodies are political and that an embodied approach to public space is fundamental in order to re-think contemporary democracies. Taking into account bodies, passions, desires, and alliances among embodied subjectivities living in public space, acting it, and creating it, as well as the arendtian idea of politics as acting in concert enriched by the feminist approach to subjectivities and political practices, it will provide a new vision of politics against the violent, and populist drifts of the latest years.

\section{The Body and the Political}

In western political theories the link between bodies and politics has been used, abused, normalized, neutralized, and sometimes erased (Loraux, 1984, 1997b; Cavarero, 2003, 2013; Castelli, 2015). While in archaic Greece's culture bodies do occupy a central role and are intended as a fundamental di- 
mension of the human life, this centrality is progressively lost in the Athenian polis of 5th century, where corporeality is reduced to the material surface of political acts of speech, thought, and action. It is a neutral element, proof of the good functioning of the civic norm (Loraux, 1984, 1997b). In the ideological athenian political discourse, male body is the soma autarkes, or the body of the warrior, expendable for the glory of the polis. There is no space for other bodily experiences, such as sick, diseased, or wounded bodies, or for the everyday experiences of labour, hunger, and strain, nor even for sex, love, or care (Loraux, 1989). The 5th century Athenian polis defines its self-representation - as a rational, free, political space of equals - proceeding to an erasure of its natural and physical roots, achieved by control and subjugation of nature and by a laceration from and against the natural (Cavarero, 2003; Melandri 2011). The Athenian polis separates bodies from human activities, and bodies from the idea of freedom and politics. Bodies find their only representation under the sign of courage and virility, and no other material experience is allowed in the official discourse. Athenian citizens are teared of their real bodies, in order to embrace an incorporeal and abstract virility entirely manifested in political institutions (Loraux, 1984, 1989, 1997b). "Hēpolis absorbs plurality in an abstract singularity; contradictions and diversity in the social body are suppressed in the notion of city" (Loraux, 2006: 351). The body, and its reference to sexual division, reproduction, care, disease, mortality, vulnerability, exposition, and to life intended as survival, enters into a symbolical collision with the official discourses, and ends up to assume on itself all those elements polis does not recognize as political or labels as dangerous for the image of "the City as One", political space of brothers in peace. Outside this official representation we find bodies, violence, conflict, nature, necessity, and women, all bond together. Women, as females, mothers, as embodiments of sexual difference, and as "the other of man", become figure of body and sex, seen both in their biological and taxonomical social definitions (Loraux, 1981, 1989, 1996, 1997a). In this framework we can understand Antigone's death under a new light. A female body buried alive outside the civic boundaries: she is the unpolitical the polis has excluded from its civic space (Cavarero, 2003: 20). Plato's philosophy has enforced this tradition, turning bodies in the ambiguous material support of psyche, the soul seen as the site of human identity. For the athenian philosopher, body is a cage, a dangerous shell, distracting philosophers' souls from the nous, and turning them to basic, animal, lower instincts. Men's destiny is to reach for the logos, seen both as the rational thinking and the rational discourse. It is a vertical, upright, and erected path, leading to Truth and Good, in strong opposition to the inclinated, exposed, and precarious experiences of the body (Cavarero, 2013). It is also true that Plato's topography of polis (and soul) as a living body, with its own functions and organs, will open to a new tradition (Cavarero, 2003). The analogy 
between political organization and human body will open the way for new images of the political, and the platonic bodily correspondance between the microcosmos of the individual and the macrocosmos of the polis will lead to the vertical and organic image of the political body, composed by a head - holding the leading role -, a chest - where lies the courage essential for the defence of the city against its enemies -, and a belly - the voracious space of artisans (Cavarero, 2013: 109).

From Plato, to Aristotle, to Medieval and Renaissance thinkers, to Hobbes and so many others, the metaphor of the city (and the State) as a living body will link bodies and politics in a new way. After a long exclusion of the body experience from its foundational categories, political orders will now structure their image on the metaphor of the political body, made of different organs and functions carried out by State in its differents parts (Cavarero, 2003: 8). The body as metaphor of the political will find a great fortune in the Medieval and Early Modern traditions, where the analogy between the head and the leading power plays a central role. In these traditions, the body is intended as an organic whole, where the head dominates the rest of the (civic) body, part of it and its instrument. The body turns into a metaphor for the political hierarchy, and, as a body, power is exposed to illness and disease, sometimes to death. Power has now an anatomy, and needs therapies against pathologies. With Thomas Hobbes the idea of political body will switch from natural to artificial: the State is big artificial body - giant, terrible, and reassuring -, composed by its servants, as the Leviathan's frontispiece clearly depicts.

All these political bodies are male bodies, pretending to be a neutral and universal images for all human beings. They are rational and disciplined. They are sovereign subjects, and they control nature, necessity, and passions. They are subjects of power. Female bodies will stay in the margins, excluded from the official political representations, since they are still seen as irrational, animal, passioned, and unpolitical. They are object of power. (Sartori, 2009: 31-32). Even when femininity seems to plays an important role in political discourse, women's bodies are erased and normalized. So it is for the many depictions of motherlands, or the modern representations of the Nation as woman and mother. Motherland gives life to warriors and citizens (as it was for the athenian foundational myth of authocthony. See Loraux, 1981), and has to be protected and preserved from aggressions. In the meantime, as female bodies and their reproductive power pose serious questions to the neutral-rational organization of political self-representation, a number of narrative dispositifs have been created over time normalizing and abstracting motherhood from mothers, erasing women bodies and praising for an abstract femininity (ibidem). 


\section{Bodies are Political}

At the turn of the last century both the body has become relevant for several analysis, debates, and political discourses. After the political experiences of the Seventies, feminisms and Foucault's biopolitics, the body has started to be considered as element of subjectivity and identity, where power can act and have effects: the body is not just a passive and material support but a spatial and temporal entity sharing the world with others, immersed in a specific cultural context. In Michel Foucault's analysis on Modernity, the body becomes the nodal point of power dispositifs, crucial site of application in the process of production of subjectivities (Foucault 1976, 1984a, 1984b). Foucault defines "biopolitics" the new relation between power and bodies in the Modern age (Foucault, 1976). Modern age, Foucault claims, starts a radical change towards the administration of life by power, as biopower (121). A technology of life comes to life, and bodies become objects of power and power strategies, both at individual and collective level. Through new insititutions (such as prisons, medicine, disciplination of sexuality) individual and collective behaviours become both objects and instruments of power structures. With biopower there are no places, situations, and dimensions separated or protected from the political.

Feminisms have introduced a new vision of the link between bodies and social identities, rooted in the idea of embodied, material subjectivities as fundamental means of political relationships. Women irrupted in public space with all those categories traditionally excluded from it - desire, passions, political relationships - putting bodies at the very center of the public scene. Feminist movements gave new centrality to the embodied dimension of subjectivities, overcoming the dichotomies upon which western political theory has built its own self-representation and identity. Subjectivities are intended as embodied, sexuated and gendered, exposed, relational, and situated. Body/mind, oikos/ polis, personal/political dichotomies are refused. Bodies are political.

Feminisms think subjects beyond mind/body duality, as embodied subjectivities, constitutively in relation with other subjects and environments. Every subject is an embodied subject, has a personal story, and follows paths in life that are not conceivable without taking into account material circumstances and situations. The body is intended as a shared and relational experience, and it is political, revealing to us our political nature. In a sense, it gives life to politics. Many of the feminist thinkers of our times have proposed precisely this idea of an embodied subjectivity and of the body as relational, political, and exposed to alterities (Butler, 2004; Cavarero 2003, 2013; Diotima, 1987, 2009; Giardini, 2004; Irigaray, 1974, 1994; Libreria delle donne di Milano, 1987; Rivolta Femminile, 1974). Feminist theories and feminist activism has unveiled a precise idea of politics - intended as shared practices among em- 
bodied subjectivities, rooted in relation and dialogue - and a precise idea of political relationships - as those generative dynamics, rooted both in dialogue and in conflict, that do give life to politics as action in concert.

\section{Embodied Subjectivities}

Embodied subjectivities have different stories, different paths, and, together they create different political alliances and political practices. Through our bodies we are immersed in specific spatial and temporal dynamics, and always in relation to something or somebody. Every human being is exposed to alterity because of her body. Our corporeality reveals the human condition as a one of dependency, contingency, and exposure, both in violence, love, and care for each other. This shared condition lead us far from the illusion of a self-sufficient, sovereign subject: we are always outside ourselves because of our bodies (Butler, 2004). Talking about embodied subjectivities means to undo the idea of an absolute individual subject, free from necessity and from any restriction, be it natural or social. It means to pinpoint interdependency, and relationality as defining attributes of being human. This interdependency, far from being disempowering, is really what constitutes us as human animals and what makes us political. Exposure is shared among humans, although it is differently socially and economically distributed. Everyone is dependent on social relations and enduring infrastructures, and is exposed to violence, care, others, and powers (Butler, 2015). To be vulnerable and dependent does not mean to be passive. To underline this condition of exposure means to fashion a non-sovereign articulation of agency. Dependency is, in fact, a condition for politics, opening up that dimension of being-together through which politics is enacted.

Dependency on others and on other living processes is at the basis of the possibility of action together. Since individuals are always related each other they will find freedom in plurality, in intersubjectivity. The body is the first means of political relationship, unveiling the subject to her plural and exposed condition. Always involved with gendered, racial and economic dynamics, the body shines a spotlight on passions, contingency, and desire for recognition, putting them at the very center of the public scene.

\section{Neoliberal Public Spaces and Bodies in Revolt}

Recent developments of neoliberalism show the urgency of a serious and new reflection on bodies and the political. In recent years we have seen the rise of new embodied practices of performing in public space that opened new spaces 
- real or symbolic, - established new orders, new relationships, and created new alliances. These embodied practices have been central to several forms of protest and resistance, and gave life to new symbolic alternatives to neoliberalism.

From 2011, which has been described by Žižek as "the year of dreaming dangerously" (Žižek, 2012), we have seen a global movement of protests in almost every continent, assuming different modalities for each different political context, claiming for specific demands. These protests were all different and had their own specific political claims but still, they all showed a common rejection of the huge contradictions of global capitalism. I am thinking of Tahrir Square in 2011, of Indignados in Madrid, to the Occupy movement both in U.S.A and in Turkey, but also to Italian movements linked to urban commons and right to the city. Not least am I am thinking of Non una di Meno, the italian intersectional transfeminist movement that arose from the Argentinian $N i$ una Menos that soon went transnational: a multi-faceted experience, tied to different territories and situations and yet connected. Maintaining a multitude of practices, uses of space and modalities of political interactions and gathering together - in a contingent alliance - an entire constellation of feminist, lesbian, transgender, cisgender, and queer groups and activists activated a shared yet heterogeneous struggle ${ }^{1}$.

This wave of protests did not refer to a univocal and common political programme, a homogeneus political identity, nor to common claims for insitutional politics. Rather, a common ground of these movements could be found in the political urgence of reappropriation of the public space and the capability of acting politically together beyond representative politics, in a shared call linking commons and partecipatory democracy. These claims were rooted in an embodied vision of politics, where politics is not reducible to institutional spaces, governments or parliaments, but happens everywhere and everytime subjects gather around the urge of changing the world together by action in concert and political dialogue. As Arendt has underlined in her works, politics in not entirely reducible to Statual organization and institutions, but rather to the organization among different subjects arising from their action in concert and discussions (Arendt, 1958). Action and speech, human prerogatives for Arendt, make it possible for humans to change their reality and take care of the world. Through concerted action and speech, politics disclose the uniqueness of every subject in plurality. Politics requires being together, in plurality. In the arendtian vision, politics is an in-between, a space of interdependency marked by relationships, contingency and materiality of individual subjectivities. Politics is a relational space, rooted in being together with others.

Protests, occupations, revolts: the latest years have been marked by a centrality of the body. Demonstrators and policemen occupied with their bodies medias' discourses, overshadowing with their corporeal, physical, visible pres- 
ence the so-called "invisible politics" of neoliberal institutions (whose effects on lives are very visible and tangible, anyway). From clashes to occupations, the experience of protesting squares forces to rethink politics in its connection with bodies: bodies that do incarnate dissent by fighting, clashing, meeting, and giving life to new political alliances.

The difference between these experience and traditional modalities of political conflict, such as those of revolutions, lies in a vision of political actors as embodied subjectivities and in the absence of abstract ideals - be it social justice, freedom, equality, or "brotherhood" - overcoming contingent and real alliances among those subjectivities. This was a fundamental point of my first book (Castelli, 2015), that led me to define these experiences "practices of revolt" - not revolutions - refusing the classical reading of revolt as a failed or immature revolution. Different from revolutions, these experiences follow different ideas of politics, agency, subjectivity, sovereignty, conflict (ibid: 51-83) and, as we will see, follow different level of efficacy.

In proximity, and physical contact, bodies in the streets embody their dissent, root it in corporeality and presence, both exposed to the contact of others and their violence. Physical proximity, and embodied presence, give those collective moments strong potentialities for political change. Here, I am rejecting any traditional interpretations of the relationship between the individual and the collective (such as Le Bon's one, 1895) that do look at crowds as moments of irrational regression to brutality, dangerous for governments and for individuals - . I am more close to Canetti's vision. Canetti has been one of the first theorists to have recognized the potential for huge political change in concerted body action and in the proximity of bodies (Canetti, 1960).

In these experiences, concerted bodily action is not to be reduced to the quantitative sense of being together. It is a reflexive gesture: individuals decide to "appear" in public space. Appearing in public space, and being in presence of others, is a key-feature of the Athenian idea of politics, and a fundamental element of the arendtian account of the political. It is an action that produces subjectivies. It is freedom embodied, as underlined by Butler's re-reading of Arendt in her 2015 work on assemblies and performative action (Butler, 2015: 24-65). Bodies, being together, enter the public space claiming for recognition, claiming their right to appear as political actors. Assemblies show that bodies are not just passive surfaces, nor just issues of politics, biopolitics, and governmentality. Assemblies pinpoint the denied fact that bodies are political, they create politics, they create and act-out public space. Bodies are political because of their relationships and mutual exposure, and because they act together and introduce the possibility of political change in the public space (Castelli, 2015).

These experiences have been plural forms of agency and social resistance, marked by sustaining relationships and action in concert. Bodies entering to174 
gether the public scene practice a right to "appear", a right to be "visible" in the public scene, in a plural and performative modality, against conditions of precarity, isolation, and dispossession of contemporary neoliberal experience. Moreover, they are declaring that "the opposite of precarity is not security", but equality relationships in dependency and equality in livable lives (Butler, 2015: 69). We live in a moment of contraction of the public scene: economic policies affect people in their possibilities of life, affecting their bodies through governance and control. We live in a social context that leads some of us to hyper-exploitation in several workplaces, where we labour in conditions of precarity, and short-term contracts quickly follow one another with arbitrary and violent rhythms. But as much as these dynamics try to make our bodies disposable and precarious, these new modalities of embodied citizenship have arisen. In a social context where invisible norms shape our lives through the economic organization of life, to bring dependency, vulnerability, precarity of our bodies in the public space is both a way to reaffirm citizenship, and a fundamental political act of revolt.

Bodies in the street pose serious questions to traditional politics (Butler, 2015: 77-78). On the one side, plural embodied, performative actions in public space pose a fundamental question: who owns the public space? [This is a very interesting and important point, that would require a huge preliminary discussion about what public space actually is, who creates it, or the possibility that public space can be owned by someone or something. I'm currently working on these issue in my next monography soon to be published in Italy, titled Spazio Pubblico]. And again: who has the right to enter it? Who is the expected subject for the public space? On the other side, bodies pinpoint political questions even more pressing, such as: what does a body need? What can bodies do together? What kind of politics can concerted, embodied action give life to? What bodies can actually physically have access to public space and to protest? These questions concern survival, health, and the claim to being part of a shared social world, at once constructed on respect and duties, that link us one to another, and is enriched by our passions, desires, relationships and care for each other. In other words, by all those passions that make us humans, and that politically unite us in a passionate way (Castelli, 2016).

\section{Giving Life to Passionate Public Spaces}

In public squares we can see enacted tactics of embodied activism. People singing, standing, occupying the public scene. A plural and embodied space comes to life, through the assembly of bodies publicly exposed. Such public spaces are fueled by contingency, fragility, and vulnerability of humans. They are pas- 
sionate assemblies, and bring passion in a plural public space, even whilst passion has been traditionally excluded from the official self-representation of the Political, limited and defined as space of freedom and reason, where there is no place for strong passions and for bodies, since bodies are vulnerable, animal, mortal, irrational, compelled by natural necessities. Bodies in squares do not just give proof of plural presence, of protest, and of resistance. They also contribute building new realities, creating new practices, opening up new political possibilities. In this sense, protesting is a way to politically mobilize shared conditions of precarity and vulnerability.

Squares and occupations produce a shift towards claims that are not necessarily involved with institutions or government. It's not a way of demanding something, it's a way to create something by living public space together, taking care of the public and the common. Occupations are not just demanding something from governments and institutions: they try to create the new world they claim of by living together, acting together, and taking care of the space they're occupying. Rooted in plural embodied relationships in and through the urban space around them, these protests do not just demand change, they realize change in new public formations.

When bodies enter the public scene they do not create an utopian space of protest: they rather give life to new communities that debunk the foundational myths of the democratic political space. Their performative practices refashion public space, its exclusions and demarcations, its norms of accessibility that define times, spaces and actors of a recognized political agency. These experiences have clarified the dispositifs of exclusion and the normative ideals upon which citizenship and access to power are built. So bodies become epicenter of broader political conflicts that runs over the dichotomies on which the polis has been built upon, and challenge the very terms of social recognition. The line of demarcation between these experiences and manifestations of rightwing dissent lies in the polarization between the two terms of "Identity" and "Alterity". As Judith Butler latest work has underlined (2015), it is true that every time we assembly and claim for change we are also asserting a "We", an identity, and, in so doing, we pinpoint an alterity. But, in my opinion, we must also consider that there are at least two different ways to approach to alterities: we can claim for their exclusion (and that is the case of anti-migrants rightwing protests) or for an inclusive, broader, justice for everyone. This may be a good point of distinction.

Protests of recent years - such as 2011's Tahrir Square, Indignados in Madrid, the Occupy Movement in the US, the urban commons and right to the city occupations in Italy, and Occupy Gezi in Turkey - differentiate themselves both from traditional urban conflicts or right-wing forms of protest. They have been heterogeneous, fragmented. Often they have been just temporary alliances of different subjectivities, and did not have real leaders, nor clear and 176 
defined agendas. They were not led by political parties (although in some cases political parties became part of them). Since they acted on a different political level, beyond the State dimension and as alternatives to State institutions, their effects have to be read in light of a different idea of political efficacy. These experience can't be seen as successful only when (and if) they finally take power, since they do not claim for institutional power; protesters do not "success" when obtaining from institutions what they are claiming for, since their claims are broader and general, and sometimes not defined by a single instance. Their efficacy lies mostly on a symbolical level. These movements tried to found new imaginaries for politics, and for social relationships, built upon exchange, action in concert, shared space for political action and speech, beyond traditional configurations of power. So we can't judge their importance taking into account traditional parameters of efficacy, duration, size, or frequency, since, as we have seen, they aim to a symbolical overturning of neoliberal values and the breaking of those enclosures and dichotomies that define our contemporary public space, our access and visibility in it. These movements have disrupted the very idea of an homogeneous, rational, and egalitarian public sphere, and have shown us what public space is really made of - conflicts, exclusions, different powers and forces -, thanks to the massive power of embodied alliances and embodied practices that, as we have just seen, give voice to passions, desires, vulnerability, interdependency, inside political space. This is why we can't simply call these experiences as ones of "revolution", since they are not trying to take over power and establish new sovereign political orders. We may call them "urban revolts", withdrawing the idea that a revolt is an aborted revolution - since, as Furio Jesi has shown, revolt and revolution are very different experience and move on very different levels (Jesi, 2000; Castelli, 2015) - .

This is also the reason why these protest often opted for square occupations. Occupying - occupare, in italian - is also taking care - occuparsi - of a shared and common dimension (Giardini, 2012). Occupying spaces is not to be intended as an attack to authorities; rather, it is a symbolic start of "a city in the city": a new symbolic space founded on new rules, refusing any hierarchical organisation, out of parties or institutional government, seeking for horizontal decision-making. The act of occupying a public space escapes from the frontal and dichotomic antagonistic dynamic of the revolutionary struggle against political institutions. It is an act of creation, that needs collective action and care, and gives life to political and social symbolical alternatives. The act of occupying a square embodies a caring for the city, since demonstrators build up and take care of new shared and political spaces. "Taking back" - to quote many of the right-to-the-city Italian movements of the latest years - a square is then a regenerative and creative act, building up a symbolic city within the city.

The intimacy subjects have with the urban space in these collective moments touches not only their personal perception of the city, deconstructing 
the spatial divisions that mark their everyday experience; it also opens to a deep relationship that orients and resignifies public space with passion and emotions, leading to a symbolic transformation in the urban fabric marked by a strong political appeal. These experiences have been plural, performative experiences, welcoming of those incalculable, non-sovereign dynamics of "being together" that upset the idea of agency as property of the sovereign self. Plural actions: individual stories conjuring together a plural dimension of politics, where the individual does not become subsumed by the collective. Subjects in those protests did not disappear in the crowd. Instead they were standing, in a political relationship and interconnection with others. Protesters did not act in unison; they acted together. This is why these assemblies differentiate from what has been depicted by Le Bon and XIX theories of the crowds: no leaders, nor abstract collectivities or abstract ideals erasing subjectivities' lives and experiences. In these assemblies everyone is different among equals. People with different experiences, with different political backgrounds, come together in a temporary alliance for a common struggle.

\section{Conclusions}

These struggles were radical but not teleological, since they were not subsumed in abstract ideals that have to be realized no matter what, regardless of individuals and their lives, and disclosed an alternative economy of bodies, emotional and passionate, recognizing bodily exposure and dependency as fundamental conditions of politics. They brought desire, social passion, and concerted action at the center of the public space. In these experiences it is possible to glimpse the possibility of a radical change, and an extension of the institutions of democracy. They compel us to rethink politics as action in concert, against normative reductions of politics to techniques of neoliberal governance. In this new and shared public scenes, bodies are central to a new idea of politics, rooted in embodied subjectivities and their social relationships. Keeping a very strong connection with other non-spatial dimensions of dissent, such as the use of social networks, hacking, networking online and offline, bodies in the streets give life to politics made of relations and political alliances, refusing delegation and competitiveness. This is close to the meaning Hannah Arendt has given to politics (Arendt, 1958) and moves on the same background on which feminists groups and thinkers of sexual difference have started their political practices from Seventies to nowadays (Rivolta Femminile, 1974; Libreria delle donne di Milano, 1987 and many others. For a survey on political practices born in Seventies in Italy, and namely in Rome, see Stelliferi, 2015): a vision that looks at politics as rooted in material lives, as a shared reality where every 
subjectivity can enter the common dimension of inter homine esse, a shared and participated space of interaction in freedom, opening up to a common world without losing singularities; a politics rooted in embodied subjectivities, in shared actions, in alliances, in practices, and in contingency, that can seriously put into question traditional ideas of political body and could save us from violent and dangerous political drifts of our recent times.

\section{Endnote}

1 Non una di meno is a large transfeminist and queer movement born in Italy in the last two years, around the urge of an alliance among cisgender and transgender women in order to face gender violence. In Italy the amount of feminicides had a huge growth during the last years. Most of those feminicides were committed by husbands, boyfriends, relatives, despite the racist rhetorics that link them to migrants. Against racist and securitarian policies, Non una di Meno has organized several assemblies and occupations, and drafted an independent feminist Plan against violence on women and gender violences. The Plan was the result of a huge collaboration, among different cities, collectives and groups, on a national scale, on different topics (escaping gender violence; laws and norms; welfare and work; sexual and reproductive health; education and formation; feminisms and migrations; media communication of gender violence; sexism in political movements; gender violence and urban spaces) and aims to be a feminist response to gender violence against sexism, racisms and populism. At the same time, Non una di Meno has organized flash mobs, occupations, demonstrations, assemblies, and general strikes that have gathered different generations of (cis- and trans-) women and different waves of feminist activists.

\section{References}

ARENDT, Hannah, 1958. The Human Condition. Chicago: University of Chicago Press.

ATHANASIOU, Athena; Butler, Judith, 2013. Dispossession: The Performative in the Political. Cambridge: Polity Press.

BERNINI, Lorenzo; Guaraldo, Olivia (eds.), 2009. Differenza e relazione. L'ontologia dell'umano nel pensiero di Judith Butler e Adriana Cavarero. Verona: Ombre Corte.

BUTLER, Judith, 2004. Undoing gender. London: Routledge, London.

BUTLER, Judith, 2015. Notes Toward a Performative Theory of Assembly. Cambridge, Mass: Harvard University Press.

CANETTI, Elias, 1960. Masse und Macht. Hamburg: Claassen Verlag.

CASTELLI, Federica, 2015. Corpi in rivolta. Spazi urbani, conflitti e nuove forme della politica. Milan: Mimesis.

CAVARERO, Adriana, 2003. Corpo in figure. Milan: Feltrinelli. 
CAVARERO, Adriana, 2013. Inclinazioni. Critica della rettitudine. Milan: Raffaello Cortina.

DIOTIMA, 1987. Il pensiero della differenza sessuale. Milan: La Tartaruga.

DIOTIMA, 2009. Potere e politica non sono la stessa cosa. Naples: Liguori.

FOUCAULT, Michel, 1976. La volontè de savoir. Paris: Gallimard.

FOUCAULT, Michel, 1984. L'usage des plaisirs. Paris: Gallimard.

FOUCAULT, Michel, 1984. Le souci de soi. Paris: Gallimard.

GIARDINI, Federica, 2004. Relazioni. Differenza sessuale e fenomenologia. Rome: Luca Sossella.

GIARDINI, Federica, 2012. Politica dei beni comuni. Un aggiornamento. DWF, 94, 49-59.

HOBBES, Thomas, 2008. Leviatano. Roma-Bari: Laterza (ed. or., Leviathan, 1651).

IRIGARAY, Luce, 1974. Speculum. De l'autre femme. Paris: Les Editions de Minuit.

IRIGARAY, Luce, 1994. Essere due. Torino: Bollati Boringhieri.

JESI, Furio, 2000. Spartakus. Simbologia della rivolta. Torino: Bollati Boringhieri.

LE BON, Gustave, 1980. Psicologia delle folle. Milan: Longanesi (ed. or., Psychologie des foules, 1895).

Libreria delle donne di Milano, 1987. Non credere di avere dei diritti. Torino: Rosenberg \& Sellier.

LORAUX, Nicole, 1981. Les enfants d'Athéna. Idées athéniennes sur la citoyenneté et la division des sexes. Paris: Maspero.

LORAUX, Nicole, 1984. Blessures de virilitè. Le Genre Humain, 10, 39-56.

LORAUX, Nicole, 1989. Les expériences de Tirésias. Le féminin et l'homme grec. Paris: Gallimard.

LORAUX, Nicole, 1996. Né de la Terre. Paris: Seuil.

LORAUX, Nicole, 1997. La cité divisée. L'oubli dans la mémoire d'Athènes. Paris: Éditions Payot \& Rivages.

LORAUX, Nicole, 1997. Un absent de l'histoire?. Metis, 12, 223-267.

LORAUX, Nicole, 2006. The Invention of Athens. The Funeral Oration in the Classical City. Zone Books, New York (ed. or., L'invention d'Athenes. Histoire de l'oraison funèbre dans la "cité classique», Éditions EHESS-Mouton, Paris-La Haye. 1981).

MELANDRI, Lea, 2011. Amore e Violenza. Il fattore molesto della civiltà. Torino: Bollati Boringhieri.

PLATO, 2006. La Repubblica. Roma-Bari: Laterza (ed. or., Republic)

Rivolta Femminile, 1974. Manifesto di Rivolta Femminile. In Lonzi, Carla (ed.), Sputiamo su Hegel e altri scritti. Milan: Rivolta Femminile, 11-18.

SARTORI, Diana, 2009. Indizi terrestri. In Diotima (ed.), Potere e politica non sono la stessa cosa, Naples: Liguori, 15-52.

STELLIFERI, Paola, 2015. Il femminismo a Roma negli anni Settanta. Percorsi, esperienze e memorie dei collettivi di quartiere. Bologna: Bononia University Press.

ŽIŽEK, Slavoj, 2012. The year of Dreaming Dangerously. London: Verso. 